\title{
ILLEGAL FISHING ACTIVITY - A NEW THREAT IN MANNAR ISLAND COASTAL AREA (SRI LANKA)
}

Augustin Siluvaithasan SOSAI *

* University of Jaffna, 57, Ramanathan Road, Sri Lanka, JA-40000, assoysa@gmail.com

DOI: 10.1515/trser-2015-0051

KEYWORDS: Northern Sri Lanka, fishing industry, fishing community.

\section{ABSTRACT}

Illegal fishing net use is one of the most serious threats to the health of the world's fisheries and for the secure employment of fishers. Illegal modes of fishing adversely affect the fishing industry according to the Fisheries and Aquatic Resource Ministry of Sri Lanka which is the regulatory body of the fisheries industry. In Sri Lanka, usage of illegal fishing methods has increased in recent years. There is an urgent need to identify prohibited or illegal fishing activities and the use of dangerous or harmful substances in fishing. The present study was carried out in the Mannar coastal area from June 2013 until the latter part of June 2014, to identify illegal, prohibited and dangerous fishing activities, and to understand the major threats and impacts on the fishing community and the socio, economic, biological and ecological impacts through field surveys and library methods. The study aims to outline appropriate planning and solutions to minimize illegal fishing and to save the coastal biodiversity and fishing community.

RESUMEN: La pesca ilegal, una nueva amenaza en el área costera de la isla Mannar.

De acuerdo al Departamento de Pesquerías y Recurso Acuáticos de Sri Lanka, que representa la entidad reguladora de la industria pesquera en esta república, las distintas formas de pesca ilegal afectan negativamente la industria pesquera y se sabe que han aumentado en los últimos años. Existe una urgente necesidad de identificar las actividades ilegales de pesca y el uso de sustancias peligrosas y nocivas utilizadas para la pesca. Este estudio fue llevado a cabo en el área costera de Mannar de junio de 2013 a junio de 2014. Se realizó una identificación de las principales amenazas e impactos de la pesca ilegal sobre las comunidades pesqueras y en los sistemas socioeconómicos, biológicos y ecológicos mediante encuestas en campos y revisión bibliográfica. El objetivo de este estudio es encontrar una planeación apropiada para minimizar y remediar la pesca ilegal así como salvar la biodiversidad costera y las comunidades pesqueras.

REZUMAT: Pescuitul ilegal, o nouă amenințare în zona de coastă a insulei Mannar.

Plasele de pescuit ilegal folosite în ocean sunt una dintre cele mai serioase ameninţări asupra crescătoriilor de pește la nivel mondial, dar și asupra siguranței pescarilor. Potrivit Pescăriilor și resurselor acvatice din Sri Lanka care acţionează ca un mecanism regulator asupra industriei crescătoriilor de pește, metodele ilegale de pescuit afectează industria crescătoriilor de pește. În Sri Lanka, incidența metodelor ilegale de pescuit a crescut în ultimii ani. Există o nevoie imediată în ceea ce privește identificarea activităților ilegale de pescuit și folosirea substanțelor periculoase sau dăunătoare pentru pescuit. Studiul de față s-a desfășurat în zona de coastă a insulei Mannar în perioada Iunie 2013 - sfârșitul lui Iunie 2014. Această abordare pune accentul pe amenințările majore și pe impactul pe care îl au asupra comunității de pescari, dar şi pe impactul social, economic, biologic și ecologic al acestor studii, studii de teren și cercetări din literatură. Studiul urmărește găsirea unui plan și a unor metode de reducere a pescuitului ilegal și speră la salvarea biodiversității de pe coastă și a pescarilor. 


\section{INTRODUCTION}

Illegal fishing net use is one of the most serious threats to the health of the world's fisheries and for the secure employment of fishers. Other illegal fishing methods include the use of dynamite, stupefying substances, other noxious, harmful materials or substances and bottom trawling methods. All of these methods are common throughout the coastal areas of Sri Lanka, especially in the Palk Bay region and Gulf of Mannar, both in northern Sri Lanka.

The Fisheries Act (1996), implemented by the Sri Lanka Ministry of Fisheries and Aquatic Resources, strongly prohibits the above mentioned illegal fishing methods. Further, since 2010, the Department of Fisheries and Aquatic Resources in Mannar District, Sri Lanka, has also taken action to prohibit illegal fishing methods, including methods such as artificial fishing devices constructed from mangrove tree logs, concrete pillars, stones, and old car bodies, as well as monofilament nets, dynamiting and tree branches for squid fishing.

The use of these illegal fishing methods threatens many marine resources, especially coral reefs, mangroves, mammals, and endangered species such as turtles. One particular social issue is the effect of such methods on the numerous small-scale fishing communities in the study region. The affected fishers have, on several occasions, made complaints to relevant authorities on this issue, but the authorities have failed to take action against them due to political interference in this region.

The fisheries sector is an important economic element for people of the Mannar district in the Northern of Sri Lanka (encompassing industries, employment and livelihood). This sector has been affected for the last three decades by an ethnic civil war. The local economy had been badly affected, with internal and international displacement, loss of property including fishing gear and infrastructure, and loss of life. With the lifting of a ban on fishing after the Tamil war (which ended May 2009), the Mannar fishing communities appreciated this move by the Government of Sri Lanka. As a result, large numbers of fishermen ventured into coastal fishing and a considerable improvement in income can be observed in this sector, and this is regarded as a major turning point for the fishing sector in the post-war scenario. However, while there is hope of restoration of normalcy in their daily lives, fishers have also had to deal with the threat of illegal fishing activities in their fishing grounds.

In order to lead to prosperity, the Sri Lankan fishing industry needs proper management. The mission gets harder to achieve with the present, very permissive restrictions within Sri Lankan territorial waters.

Illegal fishing is increasing with every day and it represents a threat to the country's fishing resources. According to the National Aquatic Resource Agency of the Fisheries Ministry (NARA), poaching will have a long-term negative impact on the fishing industry in Sri Lanka, affecting its sustainability in the future.

Sri Lanka has a vast sea area and rich marine resources, and requires the protection of fish and other valuable aquatic organisms for future generations without losing the need for short-term profits to support communities recovering from the war. The Fisheries Department noticed that illegal fishing methods have increased in the fishery industry of Sri Lanka.

According to Kumara Withana, Legal Officer of the Fisheries Department in 2010, 211 cases of illegal fishing were recorded. Along with the methods outlined above, operating as a fisher without a license is also illegal.

The Fisheries Aquatic Resource Act No. 2 (1996) as amended by the Fisheries and Aquatic resource (Amendment) Act No. 4 (2004) and the Fauna and Flora Ordinance (DATE) have prohibited five fishing methods in Sri Lankan waters: 1) use of push nets for fishing, 2) harpooning of marine mammals, like dolphins, dugong and whales, 3) fishing with moxi and trammel nets, 4) fishing with gill nets in coral reefs or rocky areas, 5) monofilament nets use. 
Not only does the Fisheries Act define prohibited fishing modes, but it also very clearly states that "no person shall use or attempt to use any poisonous explosives like dynamite or stupefying substance or other noxious or harmful material or substance in Sri Lankan waters for the purpose of poisoning, killing, stunning, disabling any fish or other aquatic resources".

The Fisheries and Aquatic Resources Department of the Fisheries Ministry, as the regulatory and implementing agency of the Fisheries Act, has empowered the Fisheries Inspectors (operating under Fisheries Directors in 14 Districts) to take action against illegal fishing methods.

\section{MATERIAL AND METHODS}

This study took a mixed-methods approach to data collection. Primary data was gathered using direct observation, focus group discussions and interviews amongst the affected fishers and their communities. Some data was recorded using a video camera. Secondary data were collected from the relevant institutions, such as DFEO's office and Fishermen co-operative societies', reports from January 2012 to December 2013. The primary and secondary data were analyzed using descriptive statistical analysis (mention any software used, or that it was coded and analyzed by hand).

\section{Description of the project area}

The study area is located in the Mannar District, and encompassed Mannar Island. It is an area surrounded by rich fishing areas. Most of the productive fishing grounds lie in Palk Bay and the Gulf of Mannar. When compared with other parts of Sri Lanka, the sea of Mannar has a remarkable marine environment suitable for fishing, with a marine coast line stretching $163 \mathrm{~km}$, from Thevanpiddy in the north to Mullikulam in the south. Encircling Mannar Island is a shallow continental shelf with rich fishing banks, pearl banks and prawn banks as well as an extensive area (3,828 ha) of brackish water and mangroves.

Fishing is a major contributor to the economy of Mannar District with $38 \%$ of its population involved in fishery. As of August 2010, 28,852 people in the Mannar District, belonging to 7,813 families, are dependent on the marine fishery sector. Of these 7,547 are listed as active fishers. Mannar District is comprised of six Fisheries Inspector Divisions (FID) covering 38 fishing villages (Fig. 1).

Palk Bay and the Gulf of Mannar coastal waters (including the continental shelf) contain a variety of species of fin-fish, shell fish and holothurians.

The total catch of fin-fish, crustaceans, echinoderms and molluscs (including chanks and cephalopods) in Mannar district for 2008 and 2009 was 5,735 MT and 6,528 MT, respectively. Shallow water species include silver bellies, bream, prawns, rabbit fish, mullet fish and squid. Large pelagic fish such as seer, rock fish, mackerel and sardine are also caught in addition to prawns and crabs.

The coastal lagoon is a shallow, tidal flat area between Mannar Island and the mainland, which holds various pelagic and demersal shore species. This diversity of marine environment with rich fish resources has been the basis for a long and strong tradition of lagoon, coastal and offshore fishing as well as collecting of marine products such as sea cucumber and chank by diving. 


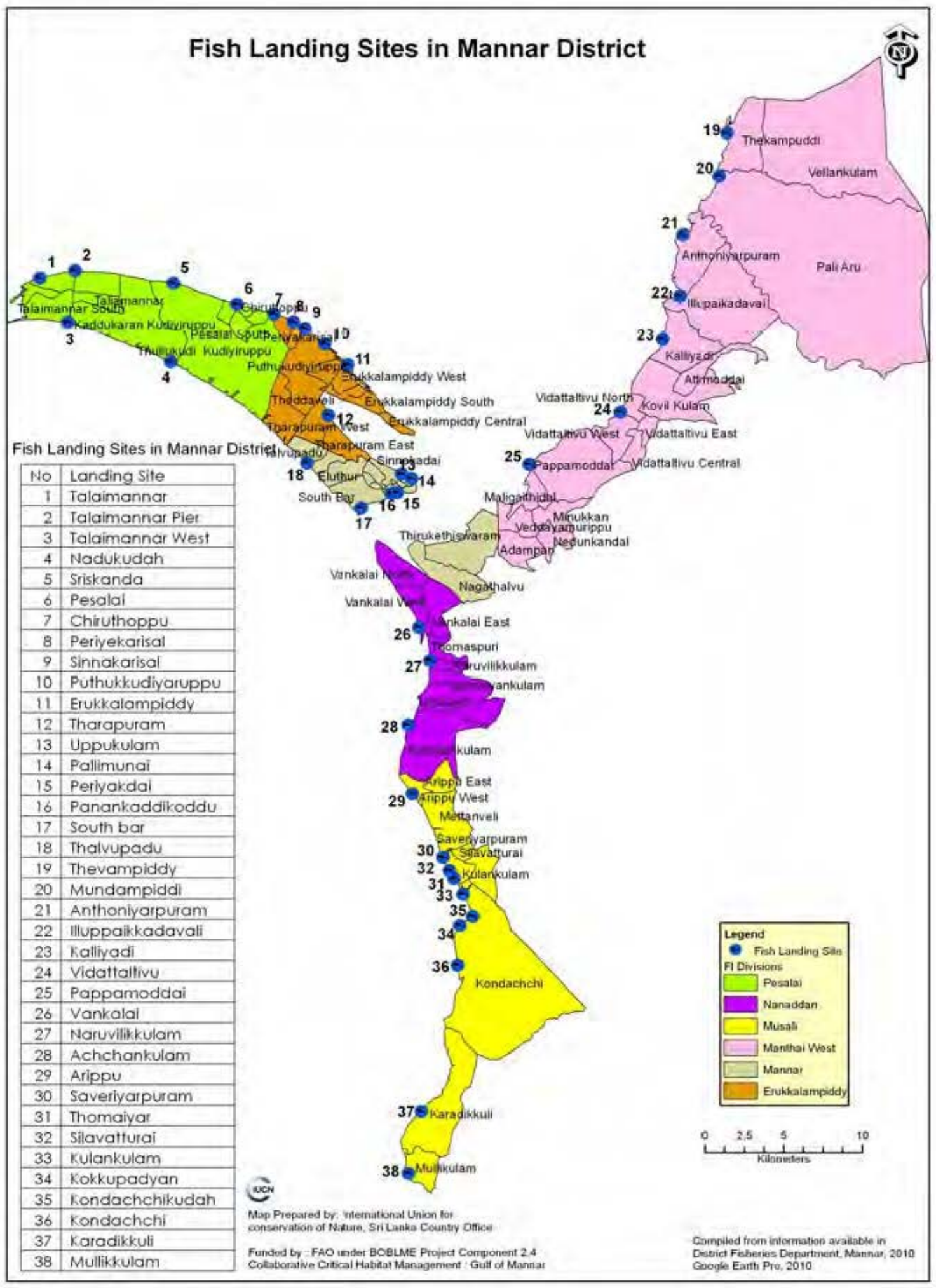

Figure 1: Fish landing sites in Mannar District. 
The landing site survey revealed that trawling is practiced exclusively in Pesalai, while gill nets, drift nets, crab nets and bottom set nets are used in all areas. Multi-hook lines targeting cuttlefish are used in Pallimunai and Vankalai, and beach seine fishery is mostly carried out in three centres at Vankalai, Thalaimannar Pier, and Nadukudah, and two centres at Pallimunai and Panankaddikoodu. More than 200 stake nets (Ja-kotu) were observed in Pappamoddai while 100-200 are operated from the Erukkalampiddy, Pallimunai and Panankaddikoodu. In addition to the above, brush piles targeting squids and cuttlefish are used in Silavatturai, Vankalai, Thalvupadu and Pesalai. Sea cucumber, oysters and gastropods (e.g. conch) are caught by skin diving/hand picking. Encircling nets (Surukku nets and Laila nets), Moxi nets and push nets and other harmful fishing methods such as dynamiting and harpooning were banned island-wide long ago, but the ban has not been enforced in the Mannar District.

\section{Objectives of the Research}

This study has three objectives: first, to identify the areas in which illegal fishing methods are used; second, to identify the major threats and their social, economic and ecological impacts on the fishing industry; and finally, to devise appropriate solutions to these threats.

\section{RESULTS AND DISCUSSION Destructive fishing practices}

As a precautionary measure, the Department Fisheries, Mannar, has, since 2010, strictly prohibited the aforementioned illegal fishing methods, including improvised fishing gear such as tree logs, concrete logs, stones, car bodies, monofilament nets and tree branches for cuttlefish (squid) fishing in the district (ADF-Mannar).

The following destructive fishing practices which are known to have an impact on the fishery resources were observed during the study:

- Dynamiting - legally banned, but still taking place between Pallimunai to Thavulpadu.

- Large stake net - is being used from South bar to Vankalai covering $10 \mathrm{~km}^{2}$ area. The Mannar court strictly ordered in 2013 that it cannot be used in this area.

- Trawling - This is presently limited to Pesalai.

- Monofilament nets (Thangus) - were being used in almost every landing site, but reinforcement of the ban from third October 2010 is in place.

- Brush piles and multi-hook artificial bait for cuttlefish were being used in two of the 14 landing sites surveyed: Pallimunai and Vankalai.

- Surukku nets (Purse seine or ring nets) - banned from third October 2010, but still being used in some areas (e.g. Thalvupadu Pappamoddai).

- SCUBA diving to collect sea cucumber and conch - banned in GoM, but fishermen from Kalpitiya still collect them in this way from Silavatturai.

- Uncontrolled exploitation collection of holothurians (sea cucumber), gastropods (conch) and bivalves (oysters) without permission or without conforming to the conditions of the permit, especially on recommended sizes. 


\section{Methods of fishing and their impacts \\ 1. Dynamite fishing:}

Using dynamite requires dynamite paste (ball shaped), a cap and a cord which is used for lighting the explosive. A stick of dynamite including a detonator (aluminium cap cord) costs Rs. 1,000 .

Usually three to four sticks are pasted together for one blast and kills fish within an area of six $\mathrm{m}^{3}$. The length of the cord is changed according to the distance and the depth of the blast, and the volume of the dynamite (two, three or four sticks) is determined by the size of the school of fish.

The man who ignites the fuse smokes a cigar or beedi. When a shoal of fish is sighted, he lights the fuse rod with the cigar or beedi, and throws it from the boat. The dynamite explodes violently, splashing the water more than 10 meters high. Soon after the explosion, dead fish can be seen floating and the fishermen jump into the water to collect them.

The use of explosives for blast fishing has been around for centuries and it is increasing. Explosions can produce very large craters, devastating between 10 and 20 square meters of the sea floor. They kill not only the target fish, but all the other surrounding fauna and flora. In coral reefs, reconstruction of the damaged habitats can take decades. Explosives are easily and cheaply purchased and often come from the mining or building industries. In many regions, explosives are extracted from old munitions from past wars or current conflicts. Elsewhere, fishermen buy them through the illegal arms trade.

Adverse effects due to the use of dynamite are witnessed in the southern part of the Gulf of Mannar. One novel illicit fishing method that developed from traditional dynamite fishing have been devised and carried out for the last fifty years by some fishermen from the neighbouring areas such as Panankattikottu and Pallimunai. Locally available cost-free discarded materials like concrete pillars, car bodies, parts of damaged boats, wooden logs, etc., are built into a structure, which is then dropped onto the sea bed. The location of the structure is marked and targeted with dynamite. Through this indigenously invented method fishing is carried out.

Once a fisherman throws dynamite in the sea there is a great probability that it might hit a coral reef. Coral reefs serve as a breeding place and gives protection to the juvenile fish. So, if the remaining coral reefs are destroyed there is a strong likelihood that fishing opportunities will be reduced, and that long-term, fishers are likely to have reduced catches and thus lose their livelihood. Within the study area, coral reefs that were historically visible above the sea surface (including Arippu, Vankalai and Silavaturai reefs) have been destroyed recently due to the use of dynamite.

In addition to these direct effects on the sea bottom, dynamite fishing, and the associated building activities to replace coral reefs, also causes a detrimental impact on the coastal and littoral environment, by driving the destruction of mangrove forest in the coastal area of Vankalai. Lots of mangrove tree logs were removed in July 2014 at Vankalai Sea (Fig. 2). 


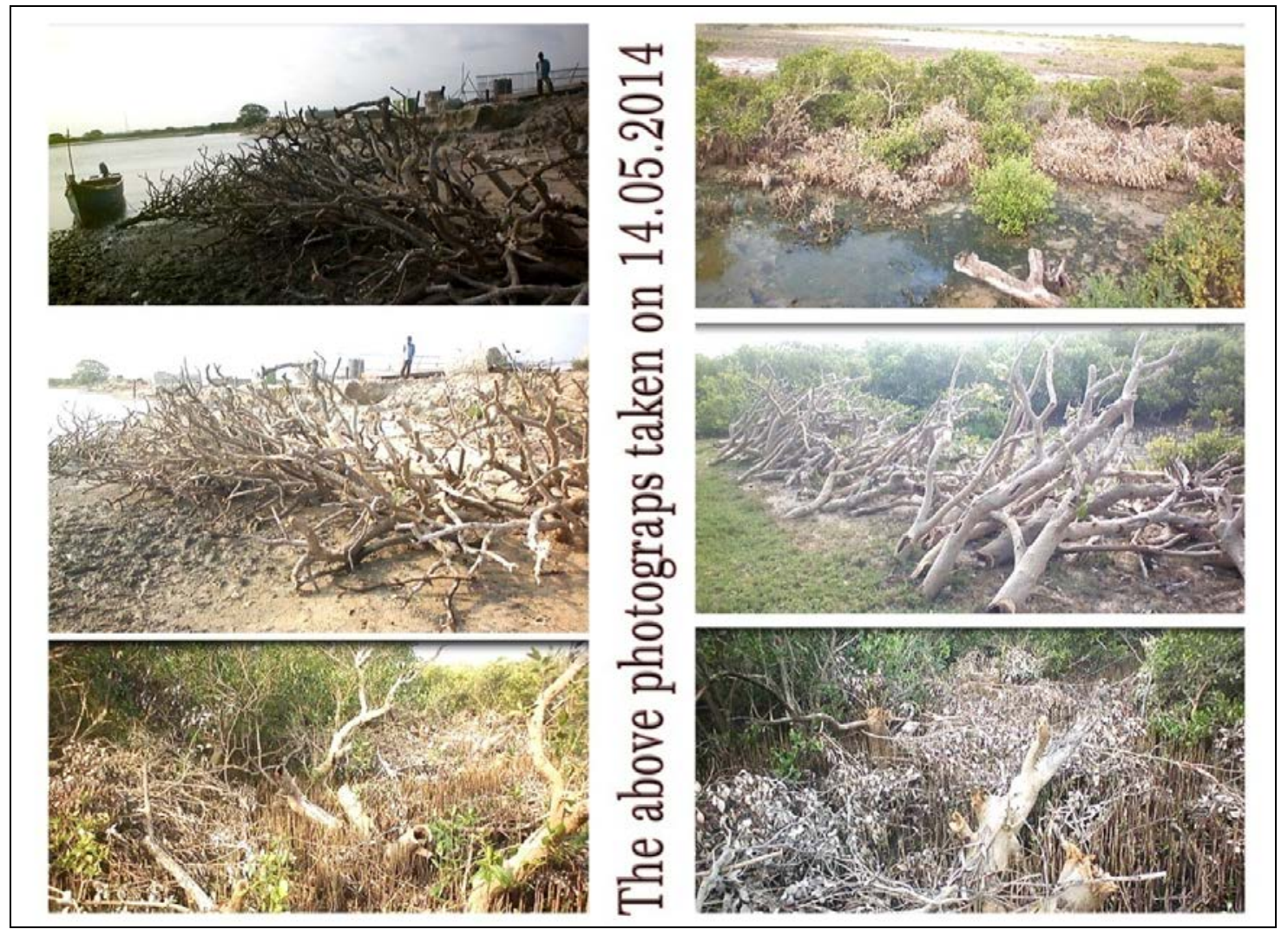

Figure 2: Mangrove tree logs removed in 2014 in the coastal area of Vankalai.

As a result of their intricate entangled above-ground root systems, mangrove communities protect shorelines during storm events by absorbing wave energy and reducing the velocity of water passing through the root barrier. Mangrove-covered shorelines are less likely to erode, or will erode significantly more slowly, than unvegetated shorelines during periods of high wave energy. Protecting mangroves sustains natural protection, and is less expensive than seawalls and similar erosion control structures, which can increase erosion in front of the structure and at adjacent properties.

Another impact of dynamite fishing is that drift nets used by small scale fishermen are also destroyed. Yet another negative consequence of dynamite fishing is the direct personal risk to the user - within the study area, several local fishermen have been maimed by explosions of dynamite, losing their livelihood (Fig. 3). 


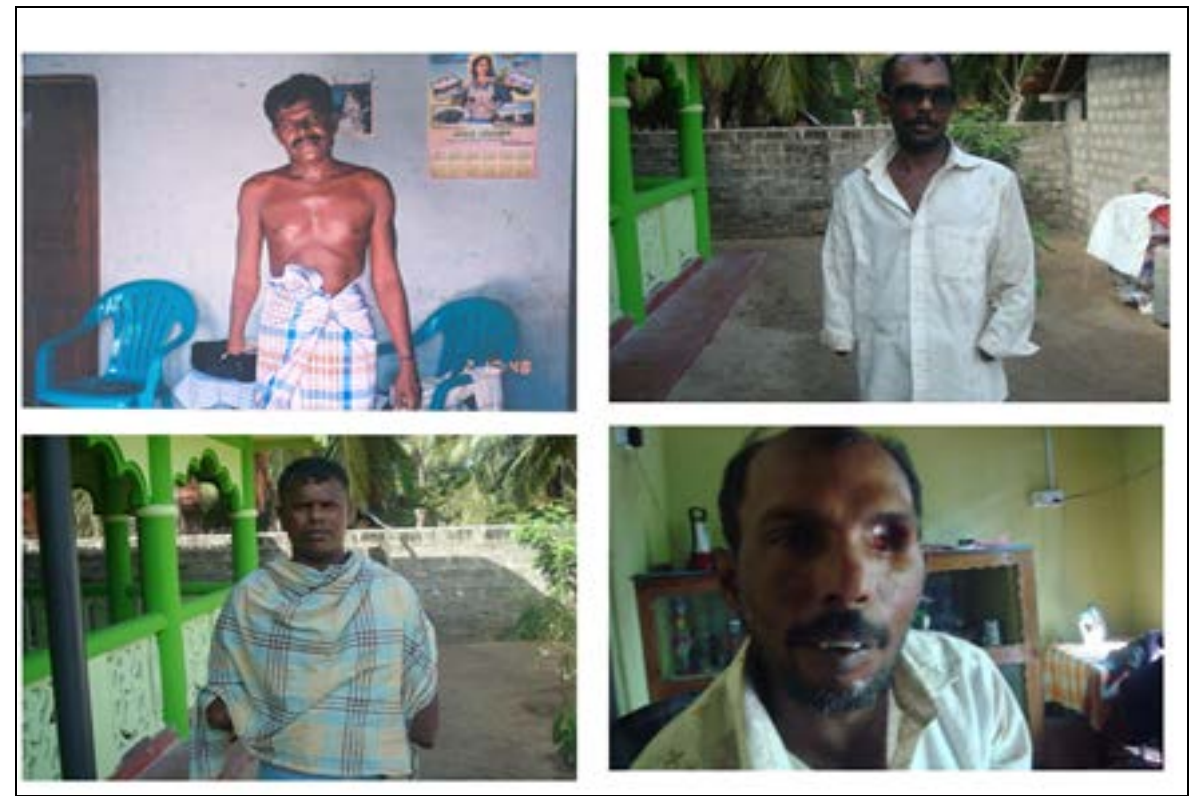

Figure 3: Injured fishermen by dynamiting.

In terms of impact on the larger animals in the area, dynamite fishing can affect endangered marine species such as the dolphin and dugong, which have been killed in the study area. Dugongs aged between 20 to 30 years old and weighing around $545 \mathrm{~kg}$ have been killed in Mannar, indicating a serious loss to the population. The corpses were confiscated by the NARA National Aquatic Resources and Development Agency, and displayed them on public at the Sri Lankan national museum on 31st December (Fig. 4).

From the above information, it is clear that dynamite fishing is both widely used in the study area despite legal obligations to stop, and that it causes significant ecological, marine, coastal and social damage.

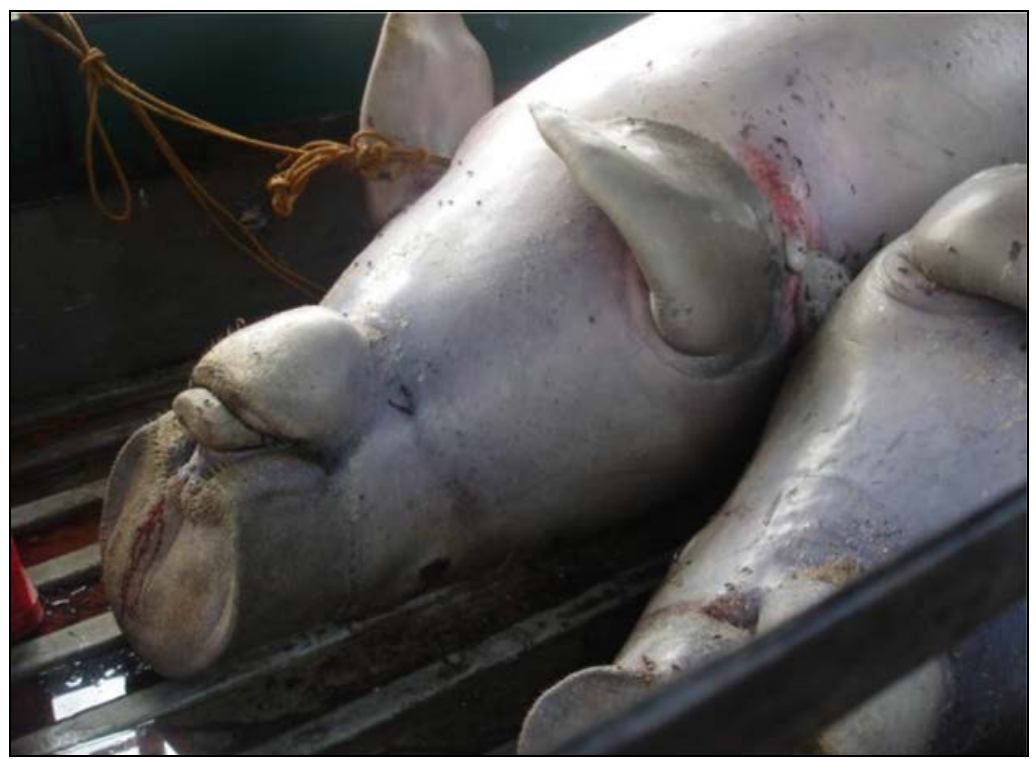

Figure 4: Dugong killed by the dynamite in Mannar Sea (Chamikara, 2010). 


\section{Large Stake nets}

The second illegal fishing method that I shall discuss in this paper is the Large Stake net or pound net. Before describing the net, I would like to note that, in my opinion, the modern type of stake net or wing net demands serious and immediate attention of the government.

A stake net is a fixed fishing device that consists of poles or stakes secured into the sea bed, with the sides covered with netting. The structure includes a pound or chamber with a netting floor, a heart, or wing and a straight wall or leader or fencing net (Figs. 5 and 6). Large Stake nets are generally set close to shore and the leader is set perpendicular to the shore to guide migrating fish into the pound.

The stake net has a long tradition in the Northern Province, but its use has always been limited to the lagoon side, its size has been limited, and only wooden poles were used.

The modern type of stake net has developed only following the recent civil war, and is significantly different (Figs. 5 and 6). Set stake nets nets are large stationary fishing gear which is set in one to $15 \mathrm{~m}$ depth in the migratory path of the target species in order to guide them in to trapping enclosures.

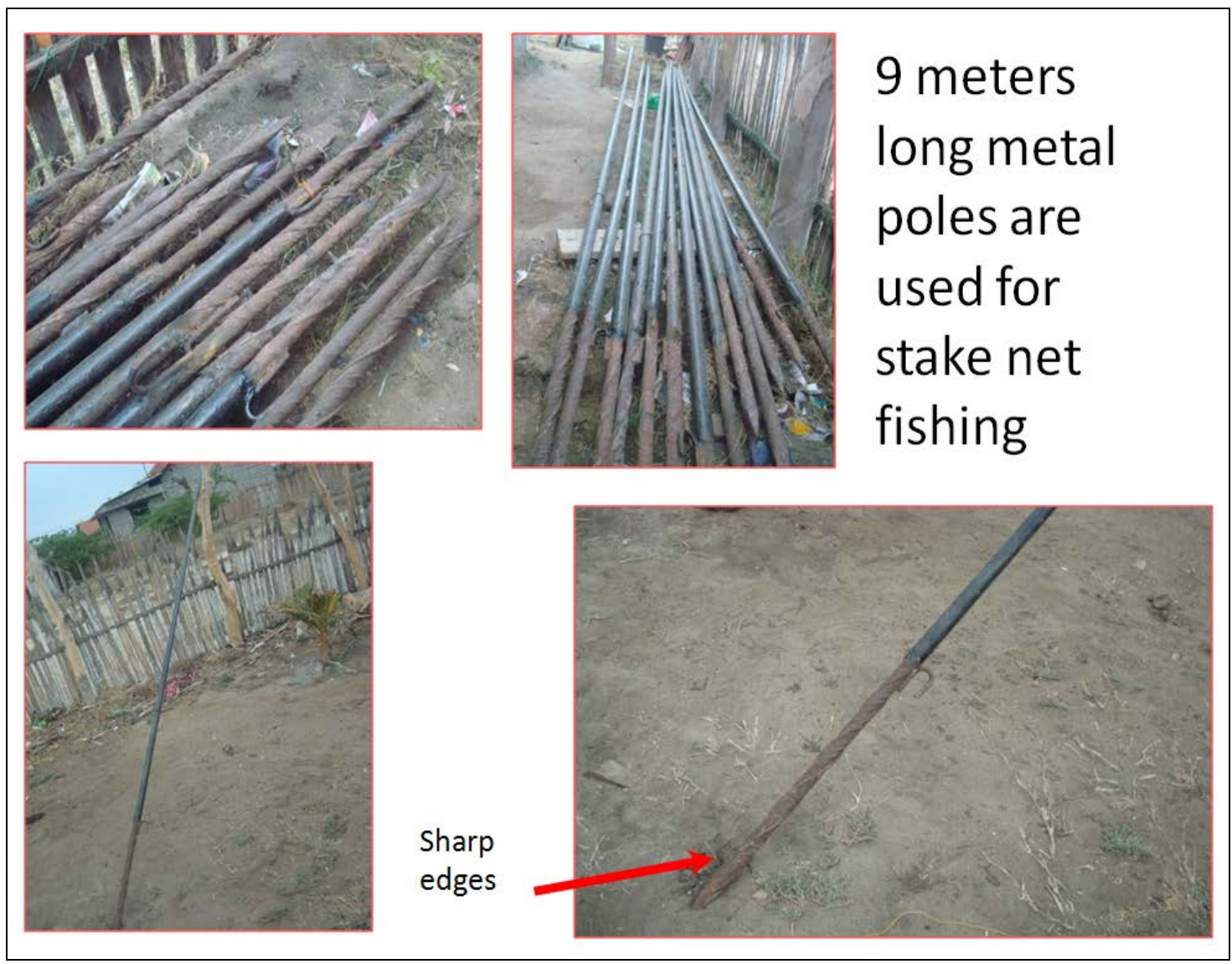

Figure 5: Stake net fishing construction. 


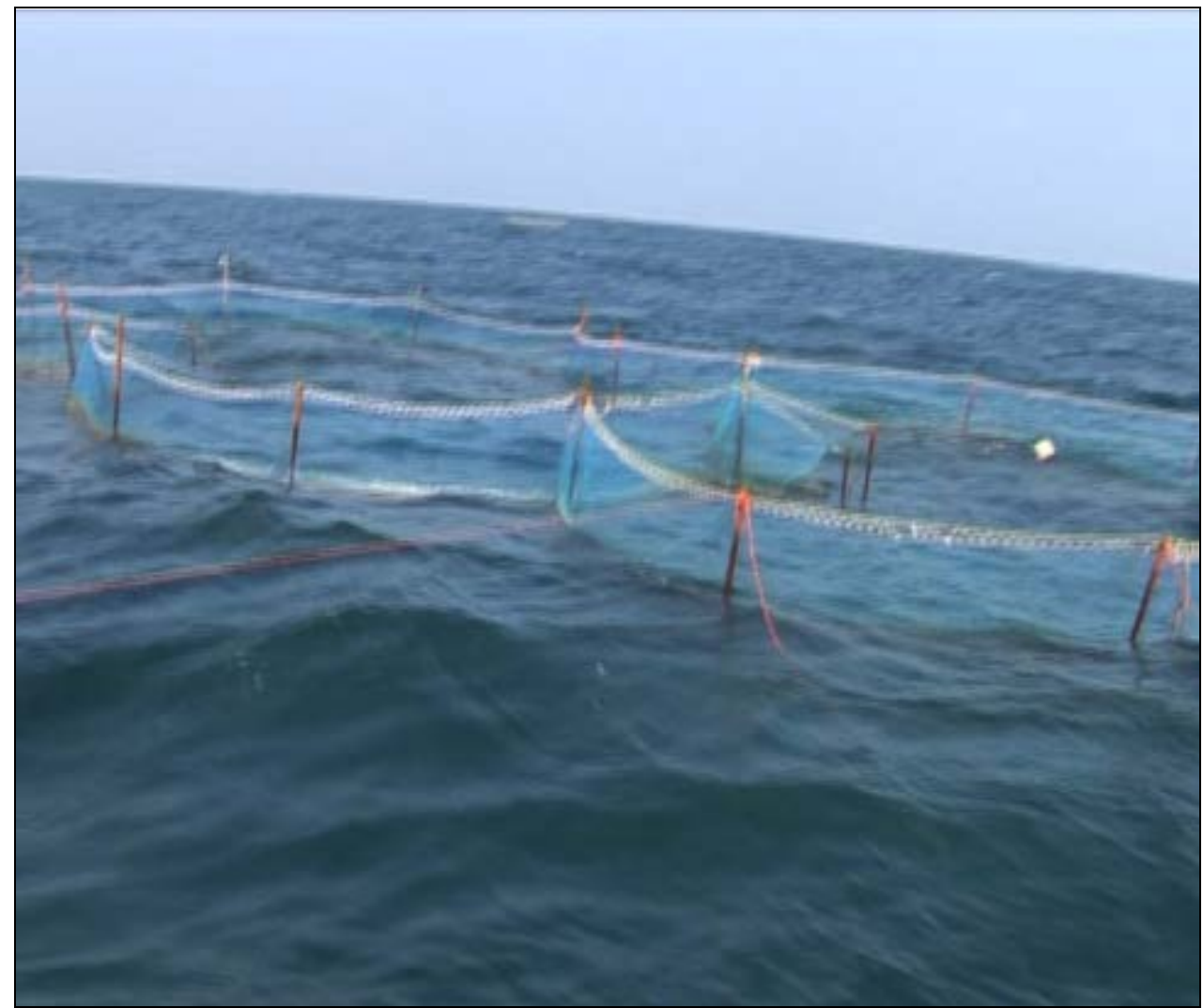

Figure 6: Stake net fishing in ocean.

This stake net is like a large fence in the sea, consisting of 20 to 50 pieces of nine $\mathrm{m}$ galvanised iron poles (very sharp), to which the enormous nets are fixed in a stretch of about $50 \mathrm{~m}$. Disappointingly, in Southern Mannar, this modern net is increasingly popular. Hundreds of these nets have been placed recently, as a whole about ten kilometres of sea is fenced in this fashion from the South Bar beach up to Vankalai Coral Reefs, with small scale fishermen and beach seiners becoming increasingly obstructed by this new illegal and dangerous fishing method.

This new netting method has the following implications:

\section{Ecological Impact}

- Marine resources, including the Vankalai and Arippu coral reefs and other marine organisms of the sea bed, have been destroyed by the use of heavy metal poles;

- Practically all schools of fish coming from the north of Talaimannar get caught in these nets, significantly restricting the movement of fish towards the shore;

- Fishermen using fibreglass boats find it very difficult to observe and avoid the protruding metal poles, especially in the dark, an issue because the poles will readily make a hole in the boats should they come into contact. A number of boats have already been damaged this way, threatening the fisher's livelihood;

- Beach seining is an important mean of livelihood for thousands of people in Southern Mannar. Due to the current presence of the wing nets, however, around 100 fishing families depend on beach seine production and 1,000 fishermen have been affected as all fish are fenced off by these wing nets. 
The use of this method provides a few people with enormous yields, while leaving others without fish, triggering a serious increase in clashes within and between communities.

As this type of nets are highly capital intensive, the fishermen involved (Pallimunai and Panamkattikottu) will not be happy to see their activities restricted and their large interests being at stake. Of course, the fishermen from these areas have only succeeded in the instalment and operation of these wing nets with the use of powerful political supporters.

Nevertheless, for the benefit of the Mannar fishing community at large, the use of this wing net should be stopped and prohibited as soon as possible. In 2013, the government announced a list of dangerous and banned fishing methods (Notice board in ADF office Mannar, by Ministry of Fisheries). Considering the above, it may be considered that the wing net is an unacceptable type of gear, against which measures need to be taken urgently to avoid further destructions and communal clashes.

Some of the victims affected by the use of metal nets have complained to the police about it. The police brought the issue to the Mannar magistrate court, through ADF/Mannar. Subsequent to investigations, the Magistrate court, Mannar issued orders for the restriction of the use of metal nets in such areas. Unfortunately the court order has not been honoured.

\section{Bottom Trawling}

This method has been banned by the ADF in Mannar since 2010, however this study has found that in Pesalai and Pallimunai fishermen are still using this method, and also that over 2,500 Indian trawlers have been observed in the Gulf of Mannar and Palk Bay region.

Trawlers destroy the sea bed in the north and south of Mannar three days a week, sweeping the bottom of the sea. Aquatic creatures are swept away by this kind of trawl net fishing, affecting the catch of non-trawl fishing methods. In addition, trawlers destroy the drift nets of local fishermen and can serious damage small boats and nets. This mostly occurs at night, when trawl boats fail to observe the long, and invisible gillnets most commonly deployed by local fishers. This results in an annual missed income of approximately six million LKR (Sri Lankan Rupees), or 40,000 LKR per fisherman, which constitutes in general about $20 \%$ of a fishermen's annual revenue (Scholtens et al., 2012).

Other measurable impacts include: local fishermen lose their valuable fishing gear, restricting them to fewer days of fishing and a much reduced income as a result; the shrimps that are the main target of bottom trawling are sourced from Sri Lankan waters but caught and processed by international boats, losing Sri Lanka Rs. 4-7 billion annually in lost prawn sales. Sri Lanka loses an estimated US\$ 750 million annually to Indian poachers, affecting around 50,000 Sri Lankan fisher families. 


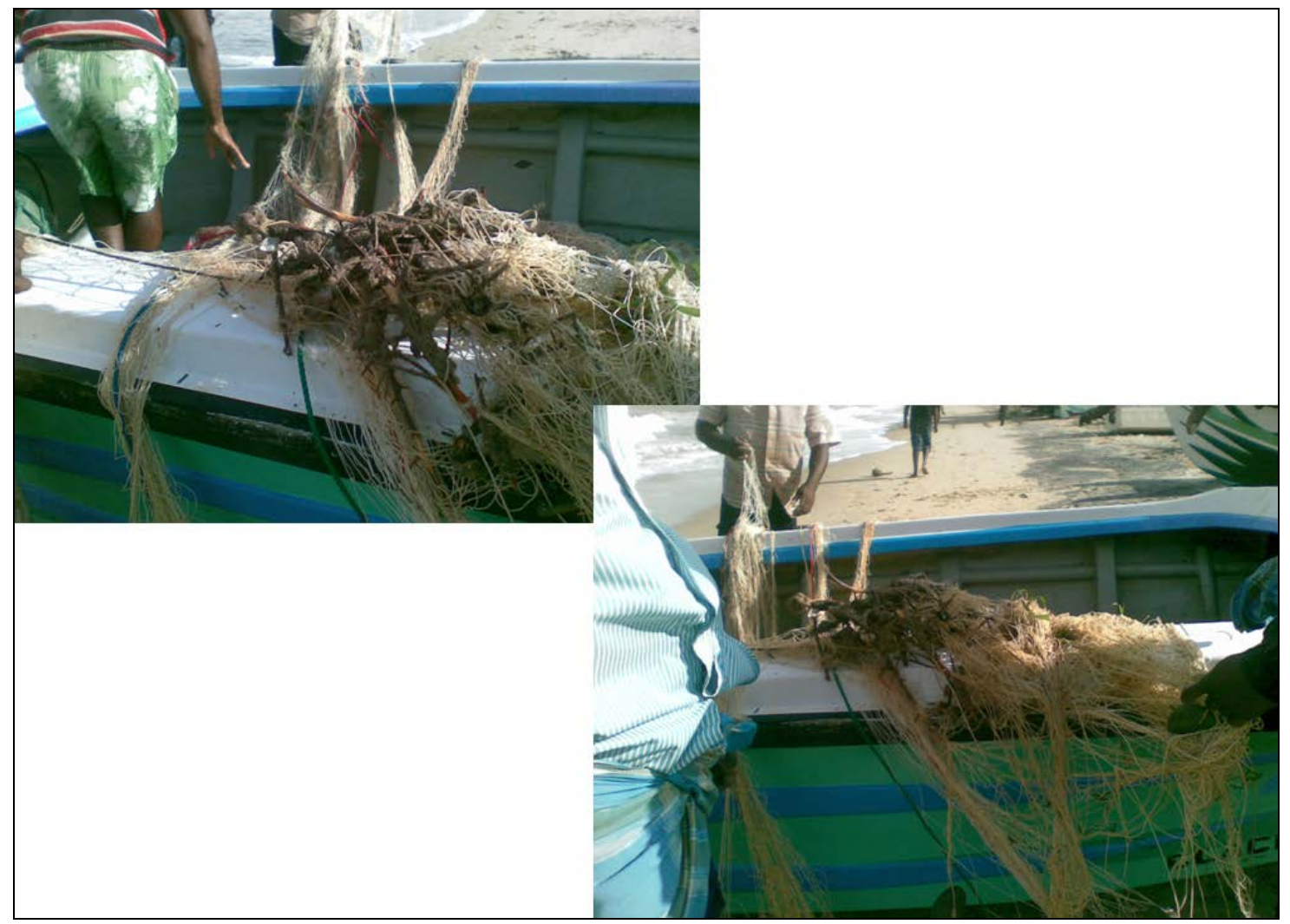

Figure 7: Gill Nets which were damaged by Tree Logs.

By-catch is also an issue with the very unselective bottom-trawling method: many species, including those at risk of extinction, are accidentally caught and then thrown back into the sea, often already dead. These collateral losses, known as discards, can reach up to $56-60 \%$ of the total catch. (Kayalvili, 2014)

In an interview with the author, the Minister of Fisheries and Aquatic Resources Development, Dr. Rajitha Senaratne, said "The fishermen of the Northern Province of our country have started their fishing activities again after the war. They never cross the Indian borders for fishing. They do their fishing within their limits in the North. But when Tamil Nadu fishermen come in thousands of huge crafts and carry on fishing according to bottom trawling method, Northern Fishermen have no place left for their fishing. This bottom trawling method of fishing they are using is banned in our country. This method of fishing has also been banned by the world food and Agriculture Organization and by the Indian Ocean Tuna Commission (IOTC). Because of this method of fishing the bottom of our northern sea and the marine environment get completely destroyed. In future it is possible there will be no fish left in the North”. 


\section{Why the law is not being implemented}

According to the Sunday Times, officials are not yet aware of the economic losses that occur when blast fishing is carried out and there are many loopholes in the existing law. As a conservationist observed in an interview, the police are expected to catch the culprits with the goods and that is difficult because the blast fishermen are in a boat out at a sea, so even if the police do get a tip-off it is difficult to reach and apprehend the culprits. The interviewee went on to say that there is also no coastguard equipped to support any police action with necessary facilities (boats, binoculars, blast detecting equipment) and no police or coastguard officials with necessary qualifications such as swimming, diving and battle training.

Another conservationist commented during an interview that the cost of enforcing the law is high and enforcement officers do not have a proper knowledge on existing rules and regulations. They also noted that political influence has played a part in the nonimplementation of such enforcing units.

"Like in other fields what we need are experts who have mandate to give an authoritative report on blast-fishing that courts can use. Like judicial Medical officers (JMOs), these experts, of course with knowledge of the internal anatomy of a fish, such as fisheries biologists from NARA and the universities should be given that mandate".

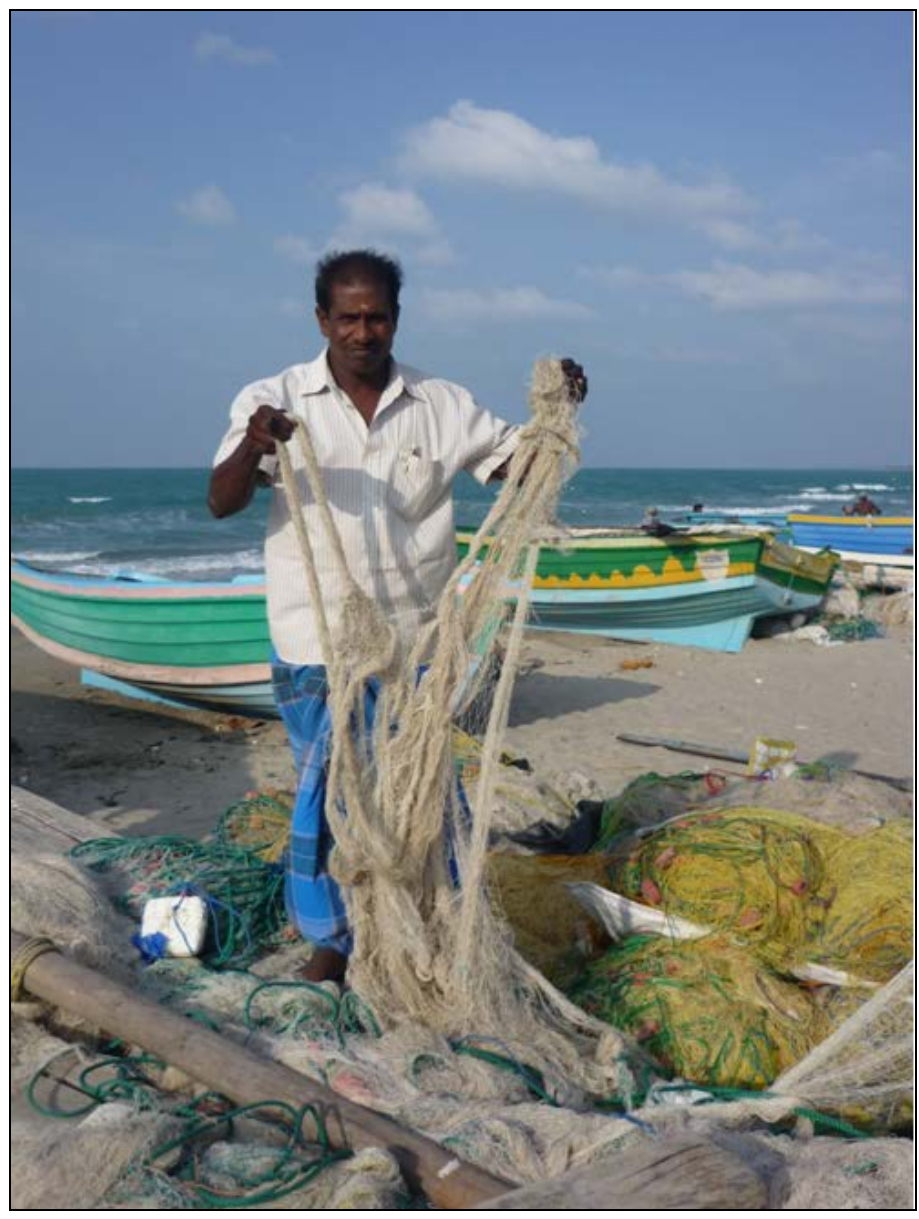

Figure 8: Damaged gills net by trawling. 


\section{CONCLUSIONS}

This study has reinforced our understanding of the detrimental impacts of certain, illegal fishing methods in Sri Lanka. When fishing techniques have been universally recognized as destructive, the only solution is to ban them. Anyone continuing to use these techniques must be severely punished.

The Fisheries and Aquatic Resource Department of the Fisheries Ministry as the regulatory and implementing agency of the Fisheries Act No. 2 (1996) and the Amendment No. 4 (2004), has empowered the Fisheries Inspectors in 14 districts to take action against such illegal fishing net. Regulations are in place, but are yet to be implemented.

According to Kumari Withana, Legal Officer of the Fisheries Department, Chapter IV of the Fisheries Act very clearly deals with the conservation of aquatic resource. The section 27 of the Fisheries Act says that "no explosive or poisonous device can be used or kept in the Sri Lankan waters. The Act has permitted the magistrate courts to impose Rs. 100,000 fine or three years to five years prison term for those who are using explosives for fishing purposes". The interviews and observations presented here support this comment, and note in particular that a lack of knowledge about, and support for, the enforcement of the low, is probably the major factor in a lack of implementation of the Fisheries Act, and the ongoing damage to fishery resources.

The cost of enforcing the law is high and enforcement officers do not have proper knowledge on existing rules and regulations, said another conservationist adding that political influence has played a part in the non-implementation of such enforcing units.

It is recommended that an awareness program should be organized to enlighten the net users of the negative consequences of the use of such nets. Regulations should be enforced, as a joint effort between the Fisheries Department, security forces and fisheries societies, for example by organizing an awareness program among the different users of marine resources in the affected area.

\section{REFERENCES}

1. Chamikara W., 2010 - Sri Lanka; Dugongs Killed In Dynamite Fishing to Be Displayed At Musium, Daily News, 31 December 2010.

2. Ministry of Fisheries and Aquatic Resources Development, 2012 - Annual Report 2011/2012, Mannar District, Ministry of Fisheries and Aquatic Resource Development.

3. Report of the Magistrate’s Court, Mannar District, 2013 May 10.

4. Scholtens J., Bavink M. and Soosai A. S., 2012 - Fishing in Dire Straits; Trans-Boundary Incursions in The Palk Bay, Economic and Political Weekly, XLVII, 25, June 23, 2012. 